\title{
Chapter 8 \\ Technology and Innovation to Weather the Storm?-A Case Study of the Role of Technology and Innovation for Startup Survival in Shanghai, China
}

\author{
Soong-Chul Ro, Zhigang Zhang, Niharika Dayaneni, and Renan Chen
}

\begin{abstract}
This chapter examines the challenges faced by startup companies in China during the great lockdown caused by the COVID-19 pandemic in the first quarter of 2020. A study of six startup companies in Shanghai is conducted focused on the nature of challenges they have faced, their responses to these challenges and the prospects for the post-pandemic business world in their respective area of business. Particular attention is paid to the roles of technology and entrepreneurship ecosystem involving venture capitals, incubators, and governments. The results lead to the conclusion to exercise caution regarding online technologies but highlight the importance of the entrepreneurship ecosystem for startup survival during the pandemic.
\end{abstract}

\subsection{Introduction}

Pandemics are not a new thing in human history, but the COVID-19 pandemic, together with the restrictions imposed by governments to contain the spread of the virus, affected many aspects of life for nearly everyone on the planet. "The Great Lockdown" of 2020, as the International Monetary Fund (IMF) described it, is now predicted to become an economic crisis much worse than 2008+ global financial crisis, contracting the world economy sharply by $-3 \%$ in 2020 (IMF 2020).

\footnotetext{
S.-C. Ro $(\varangle) \cdot$ N. Dayaneni · R. Chen

UM-SJTU Joint Institute, Shanghai Jiao Tong University, Shanghai, China

e-mail: soong-chul.ro@sjtu.edu.cn

N. Dayaneni

e-mail: neha_shashi21@live.com

R. Chen

e-mail: adriana_chen@sjtu.edu.cn

\section{Z. Zhang}

Shanghai NeoBay Venture Capital, Shanghai, China

e-mail: zzg@neobay.cn
}

J. Lee and S. H. Han (eds.), The Future of Service Post-COVID-19 Pandemic, Volume 1,

The ICT and Evolution of Work,

https://doi.org/10.1007/978-981-33-4126-5_8 
Such a deep crisis is affecting startup companies all over the world as well. Once regarded as the source of innovation, jobs and new vitality in the market, startups are now facing the battle for survival. In the US, troubled startups led to the elimination of almost 4,000 jobs in March 2020 alone, and more workers were sent home on furlough or standby (CNBC, March 31, 2020). The freezing of Venture Capital (VC) is one problem that affects startup companies. In China, VC-backed deals dropped to six-year low and the startups were asked to go into 'hibernation' (South China Morning Post, February 21, 2020). According to the World Economic Forum, the entire global startup community is facing a crisis due to the lack of investment. China, ground zero of the pandemic, recorded a $74 \%$ drop in the number of Series A + deals in February 2020 compared to December 2019. Similar drops were observed in other parts of the world. Asia (excluding China) experienced a 44\% drop and Europe and the USA recorded 14 and 6\% drops even at this early stage of the global spread of the pandemic. if the world follows the same trend as in China, WE Forum warns, it will amount to \$28 million being wiped out, and if this current dry-spell of VC deals last six months, "a large portion of startups will be wiped out" (WE Forum, May 2020).

It is not all doom and gloom though. Technology-based startups in certain areas, such as telehealth, fitness, and remote work, are finding new opportunities during the crisis (CNBC, April 22, 2020; Financial Times, March 18, 2020). Especially in China, where "the world's largest work-from-home experiment" took place with an estimated 50 million homebound customers, the crisis was seen to be an opportunity for businesses such as online education, online grocery, online entertainment and so on (South China Morning Post, February 21, 2020).

In the face of such an uncertain time for startups, this chapter attempts to contribute a part of the answer to the question of startup survival through a case study of startup companies in Shanghai, China. Shanghai has been pursuing development led by the finance and service sector empowered by technology, and in $2019,72.7 \%$ of the overall GDP, or 2.7 trillion RMB, of the city's GDP was in the service sector (Xin Min Wan Bao, March 10, 2020). Then just after the start of the Chinese New Year in 2020, the whole of China went into a lock-down and the service sector faced the hardest challenge. Businesses scrambled to go online but not all the attempts were successful. Even before the COVID-19 pandemic, Shanghai had numerous technology-oriented business incubators and industry clusters, churning out startup companies with techsavvy young entrepreneurs, but the onset of the pandemic created a deep divide between the winners and losers. This raises a question: what makes it possible for some companies to successfully adopt innovation and survive the shock, but others fail? To find an answer to this question, we conducted a qualitative case study of young startup companies in the service industry.

We are particularly interested in the actual difficulties faced by startup companies, and whether technology, especially the online technologies, could be an answer to their survival and whether there would be lasting effects of the current crisis in the post-pandemic business world. For this, we have carried out semi-structured in-depth interviews with six startup companies listed in Table 8.1. Five of these 
Table 8.1 List of startup companies interviewed

\begin{tabular}{l|l|l|l}
\hline Company & Main area of business & Years in operation & Current stage \\
\hline Company A & $\begin{array}{l}\text { Business consulting services } \\
\text { and cultural immersion } \\
\text { tourism }\end{array}$ & 3 & $\begin{array}{l}\text { Founder mentored by } \\
\text { neoBay, established } \\
\text { outside neoBay }\end{array}$ \\
\hline Company B & $\begin{array}{l}\text { Educational tourism and } \\
\text { exposure }\end{array}$ & 1 & $\begin{array}{l}\text { Founder mentored by } \\
\text { neoBay, established } \\
\text { outside neoBay }\end{array}$ \\
\hline Company C & STEM education & 6 & $\begin{array}{l}\text { Finished incubation from } \\
\text { neoBay and became } \\
\text { independent }\end{array}$ \\
\hline Company D & Disinfectants manufacturer & 3 & $\begin{array}{l}\text { Currently being incubated } \\
\text { in neoBay }\end{array}$ \\
\hline Company E & $\begin{array}{l}\text { Robots for intelligent } \\
\text { manufacturing }\end{array}$ & 2 & $\begin{array}{l}\text { Currently being incubated } \\
\text { in neoBay }\end{array}$ \\
\hline Company F & $\begin{array}{l}\text { Robots design (cleaning } \\
\text { robots) }\end{array}$ & 3 & $\begin{array}{l}\text { Established outside } \\
\text { neoBay; seeking series A } \\
\text { funding }\end{array}$ \\
\hline
\end{tabular}

companies are directly or indirectly affiliated to neoBay Venture Capital (https://neo bay.cn/home/abou) which provides an innovation and entrepreneurship ecosystem in cooperation with Shanghai Jiao Tong University, Shanghai Municipal Government, and Shanghai Land Group. Inspired by the idea of "incubator 5.0", neoBay creates a comprehensive entrepreneurship ecosystem in close partnership with other organizations in public and private sectors to provide policy guidance, financial services, legal consultations (including intellectual property rights protection), as well as accommodation, catering, fitness and so on. It also works with a range of other local innovation support groups such as Peeli Ventures, EFG, Sensor Space, South Science \& Innovation Training base, School of Design of SJTU, Advanced Industrial Technology Research Institute (AITRI) of SJTU. In 2019, neoBay has extended its ecosystem globally through the International Ecosystem for Innovation and Entrepreneurship (IEIE), linking innovation ecosystems around the globe based on the principles of equality, mutual respect, win-win cooperation, good faith, and non-intervention in internal regulation. IEIE is an international collaborative mechanism for sharing resources, matchmaking, and technology transfer in innovation and entrepreneurship, providing opportunities to access different markets as well as relevant industries for businesses in participating ecosystems.

Of the six companies interviewed, two are currently located within neoBay's incubation facility, one has finished incubation period successfully and moved out of the neoBay facility in 2019 , and the other two are founded by young entrepreneurs with previous experience in being incubated in neoBay and have received mentoring from neoBay's entrepreneurship program as an undergraduate student in the past. The last one was introduced to us by one of the companies. In terms of the business areas, one is involved in tourism, two in education, three in technology products 
including robots. Interviews and follow-up interviews took place throughout May 2020 focusing on three broad areas of interest: (1) the challenges they faced during the pandemic, (2) responses to those challenges and technology utilization, (3) prospects for the post-pandemic period. Most of these interviews were carried out online but two of these interviews took place in their offices face-to-face with the easing of the restrictions in Shanghai. Three of these companies are not in the service sector, however, our focus here is to understand the roles played by the venture capital and entrepreneurship ecosystems as an area of advanced business service during the crisis and for this, we incorporated experience of neoBay Venture capital and another venture capitalist to triangulate and get broader perspectives.

In the following parts, we will first describe the spread of COVID-19 and the government responses which formed the backdrop for the challenges faced by companies. This will be followed by descriptions of each case and discussions on the challenges, responses, and prospects for the future.

\subsection{Case Description}

\subsubsection{Responses to COVID-19 in China}

The first official actions by the National Health Commission on epidemic prevention started on January 14, 2020. By January 20 it was officially confirmed that the virus can transmit human-to-human, then on the 23, on the eve of Chinese New Year, an emergency was declared in Wuhan and the city went into an official lockdown sending a shockwave of uncertainty and fear throughout the country during the busiest long-distance travel season of the Chinese New Year. Soon, the people in the whole of Hubei Province were banned from leaving houses except for buying daily necessities for survival, and even then, under strict control. Such control spread throughout the country within the next few days as more and more cases of infections got discovered (China Daily, January 22, 2020; February 1, 2020). For about two months, travel became strictly restricted throughout the country. People coming in and out of residential areas had to be checked for symptoms of the virus, and people returning from outside the country had to go into a 14-day quarantine. Schools delayed opening till March and when they opened all classes were online. Nonessential gatherings were more strictly restricted for longer. National Parks and public places including Disneyland in Shanghai closed until May 11, when the pandemic was well under control (Xinhua, May 11,2020). Religious meetings such as churches and temples have not reopened as of May 2020.

The lockdown gradually eased starting in March. On March 4, State Council announced that work resumption could be carried out in an orderly way. Schools were also notified to allow middle-school students and fresh graduate students to come back from April 27, while ensuring their safety (China Daily, March 24, 2020). By May things began to recover. Offices, factories, and public places started to 
resume works and more people came back to work through unobstructed roads, and most entertainment venues reopened, although health monitoring such as temperature checks continue in public places and some eateries do not allow dining-in customers and rely on take-outs.

During the two months of tight control, economic activities in China froze. People spent more time at home, directly decimating incomes of the businesses that relied on people being outside, such as hotels, tour operators, shopping malls, restaurants, (nonofficial) education, and entertainment. Those located around big tourist attractions got especially seriously affected. Added to this was the sharp decline in venture capital. As shown in Fig. 8.1, VC investment in the first quarter of 2020 amounted to only $38 \%$ of the previous year in terms of invested amount (in USD) and $26 \%$ in terms of cases.

The month-by-month figure of VC investment in China shows a bounce back in March: up by more than $150 \%$ from February, followed by a slight drop in April, and another slight drop in May in terms of the amount. The number of investments made in May fell by $27 \%$, from 352 cases in April to 256 cases but the amount dropped only $3 \%$ from 9.04 billion USD to 8.75 billion USD, showing a strong tendency for the investment to concentrate around a smaller number of projects. All in all, although some recovery is visible, the figures of VC investment until May does not show signs of a full recovery (Fig. 8.2).

During this period, the governments of China at various levels worked out policies to support startup companies. For example, on February 7, the municipal government of Shanghai published a 28-points policy measure for "the epidemic prevention and supports \& services to the sustainable development of enterprises" and on February 12 Minhang District Government echoed similar policy and published " 10 policies supporting the stable development of enterprises". The specific measures included reduction or cancellation of taxes, reduction or cancellation of rents, creation of special support funds for struggling companies as well as 'technology innovation

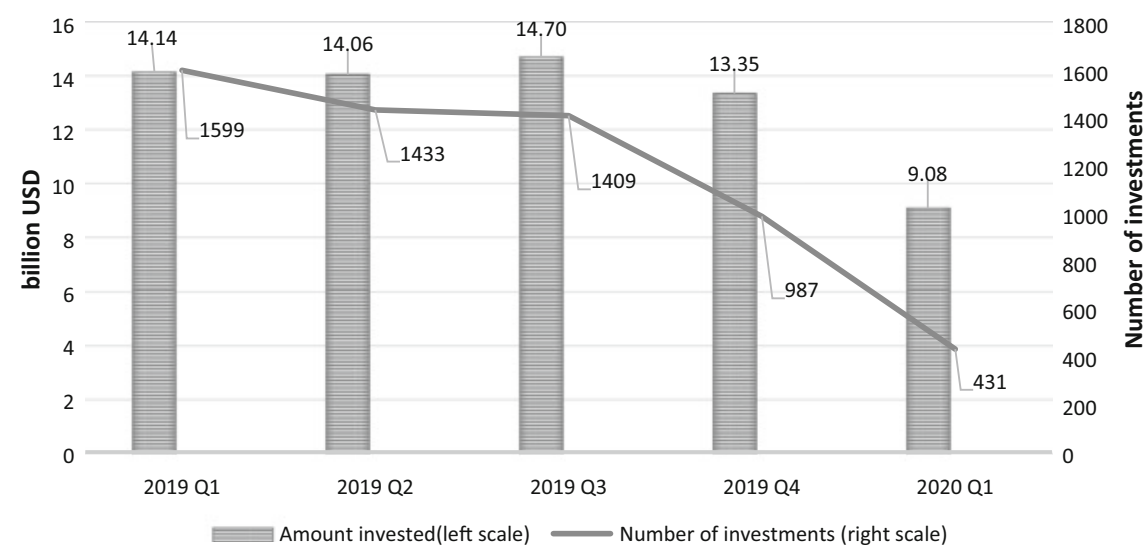

Fig. 8.1 Investment in China's venture capital market from Q1 2019 to Q1 2020 (Data Source chinaventure.com.cn, June 24, 2020) 


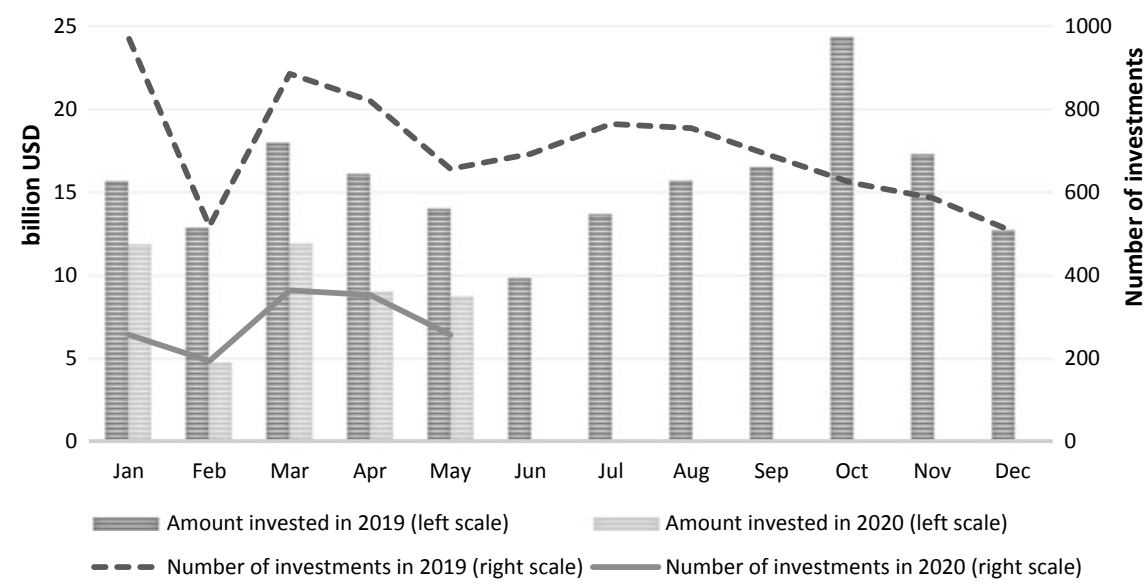

Fig. 8.2 Investment in China's Venture capital market from January 2019 to April 2020 (Data Source chinaventure.com.cn, June 24, 2020)

support funds' and green channel for innovative projects that were deemed vital in the efforts to support livelihoods of people during the lockdown (Shanghai Municipal Government, February 7, 2020; see also Shanghai Bendi Daily, February, 12, 2020). This is the background upon which the companies we have interviewed waged their battles for survival.

\subsubsection{Startup Cases: Impacts and Responses}

Company A has been in business for about 3 years. It is often mistaken as a niche market tour company that provides guided tours for unique and unbeaten tracks in Shanghai but it is much more than that. According to the founding CEO, Mr. Zhu, a young entrepreneur of barely thirty who also has rich experience in international social and educational entrepreneurship, the company aims at making positive impacts to the world by providing cultural immersion and educational experience to various groups of foreigners such as business people, students and educators, artists, officials and so on, customized to their needs. Many of the customers are business people who want to learn about China's environment and therefore it is more properly a consultation company connecting the world's brands and merchants, whether large or small, with China's businesses and consumers.

Before the pandemic, it was actively developing explorative learning programs aiming at cultivating cross border business culture through actual (offline) visits and meetings in and around Shanghai. It is not hard to imagine the impact of the pandemic on his business. All the planned visits by his customers in the first quarter of 2020 had 
to be canceled or postponed indefinitely. China is recovering from the lockdown fast and all service sectors are gradually returning to business but the conditions in other countries affect international travel and without knowing when international travel will be possible, working out plans to find new customers became an impossible task.

Therefore, business innovation, according to Mr. Zhu, is not for scaling-up or expanding into a new market, it is a matter of survival. The first step he took was an overhaul in the company's operational model. Team discussions and meetings incorporated more online technology to maximize cooperation while working from home and the company also had to go through job cuts while remaining workforce, including Mr. Zhu himself, took salary cuts. The circumstances created by the Pandemic, the "everything-through-internet" environment, according to Mr. Zhu, has forced him to refocus on the very core of what the company needs and what it can provide its customers and shake all the nonessentials out. "Everything-throughinternet" also applies to his market as well. The only way of getting customers during the pandemic for the company was to embrace online technology and adapt to the company's main service to this new environment through innovations. In this respect, the company is currently putting all its efforts to apply innovations: to find an entry point into the market, to redefine the core appeals, and carry out its business with targeted, concerted, and innovative efforts. One example is the virtual workshops and programs that the company implemented since February. Such online medium reduces the costs in terms of both finance and time, and Mr. Zhu hopes that it will also help him not just survive the pandemic but to develop a better understanding of Chinese market through the instant online access to partners within different locations in China who are now also getting accustomed to online-based meetings and events. He says it is hard to see how much fundamental changes the pandemic has brought to his business but certainly, the world is becoming more accepting of online meetings and events at least during the lockdown. How much will this remain in China and outside after the pandemic remains to be seen but he is positive that the lessons learned during this difficult period will also help him when the pandemic is over.

Company $\mathbf{B}$ is a very young company-about a year old—run by three people altogether. Mr. Sun is the young co-founder of the company which focuses on organizing educational tours for high school students in smaller cities in China to visit top universities located in Beijing and Shanghai. These tours are mixed with lectures by the faculty and experts providing an experience of university and also helping the students and parents understand different majors and future career paths. Before the pandemic, this company was on the way to take-off with four top universities of China as main partners, working out plans for students to stay in Beijing and Shanghai in hotels that have also agreed to become partners to provide accommodation, food, and venue for group activities to the visiting students and parents. His company was on the way to scaling up the operation by acquiring more high schools and strengthen trust with them with the long-term ambition of enlarging the scale of impacts all across the country and beyond. 
The onset of the pandemic shook the whole foundation of his business. For one thing, all the tourism-related businesses have been cut off by the government under the strict traveling restrictions. Even the movement of goods became restricted for a time, not to mention the movement of teenaged students in groups from one city to another. For another, the key competence of the education tour lies in the trust from the schools that agree to cooperate with his company. During the pandemic, the safety of students became any school's top priority, and no one in managerial roles of a school is willing to run the risk of being called responsible for even the smallest possible chance of exposure of the students to the virus. High schools gradually opened classes starting from around mid-April but as of May 2020, no school in China allows anyone not immediately working or studying at the school into campus and this applies to universities too. Schools agreeing to organize students in a group tour to visit universities in other cities has become too much of a risk: it will probably remain so for a while longer after everything else returns normal.

As a graduate of a top engineering school in China with a degree in computer engineering, Mr. Sun is familiar with all the technologies that are being tried in education, such as VR or preference algorithms and so on. His business before the pandemic, however, focused on communication skills and he was not very keen to explore these technologies as an option for his business. The pandemic changed the situation. Demand collapsed totally but he is not particularly worried about the profit. The company does not have an urgent financial problem for survival: it has enough investment from before the pandemic to survive several months and a small team of three people does not require much anyway. He is aware of various financial support from the government but does not feel the need even to actively inquire about them for the time being. The problem is being forgotten by the existing customers and partners as well as the pressure to do something to remain in touch. Hence Mr. Sun's company has started to actively switch their business to online lectures and consultation, utilizing existing social media apps and platforms. The company has already held several online events to guide parents and students to learn more about university education, different majors, and how best to prepare to get into good universities. Currently, he is focusing on increasing the quality of the consultants and guest lecturers at the same time as finding ways to maintain and expand customer-base as well as gain their trust. As of now, the company is still exploring and experimenting with different operational models, contents, and core services, and feeling its way into the new set of rules regarding cost and income in this new market.

Overall, Mr. Sun feels that the trust between him and the clients is somehow more stable than before. He attributes this, in part, to the fact that all stakeholders in education have now experienced and got accustomed to the online channels. His instant messenger account is becoming inundated with questions from anxious parents and it became easier for him to deliver advertisement of his company's activities to parents and other partners. There is also a sudden increase in the number of contents and platforms. This in turn gave parents and educators plenty of exposure in different platforms and contents, making them more seasoned reviewers of online education products. Apart from the changes in customers, he also thinks that there is an important change in the industry due to the pandemic. Boundaries between different 
types of businesses are becoming thinner and educational businesses are no longer simply delivering courses to students: it already blends tourism, event management, media/contents creation, and various types of consultations including education, employment, and business. At the same time, the online environment is making the branding power of existing national or international extra-curricular education providers less important than the contents they deliver. For one thing, parents, who pay for the education, now has the chance to screen the actual contents of the education and observe their children's reaction more closely than when the education was happening behind the closed doors of the classrooms.

Looking ahead into the post-pandemic period, Mr. Sun thinks that there are too many companies crowding into online education, exploring all sorts of areas of information gap for an opportunity and he thinks it will be too risky to regard online education as the main market for him. Furthermore, he started this business to help students and parents get better prepared for universities and to help them make informed choices about higher education. He also believes that knowledge is best acquired through experience. For this, he thinks online platforms are too limited and, although he is likely to keep online-based events as a way of maintaining contacts with new clients, his company will return to off-line based experiential tours and consultations as the main focus of his company.

Company $\mathbf{C}$ is another education-related company that focuses on providing science and innovation education for teenagers. The company started in neoBay about six years ago but finished its incubation period and has moved out of the facility of neoBay in November 2019. Earlier on, the company used authorized course materials developed by other companies to deliver computer-related education. Recently, however, Mr. Qian and 10 employees of the company put much effort into developing their own material that delivers more than coding training, aiming at increasing innovation and design capacity of teenagers in China.

Before the pandemic, Mr. Qian's company had operated offline to expand the influence of its products and to put its self-designed courses to practice. Although he had put some resources and time into making content deliverable online, it was designed to be used by a trained teacher in the face-to-face classroom situation. The outbreak of the pandemic has made his offline-based business unable to continue and forced him to reconsider the online option. Nevertheless, he remains cautious in moving his business online. This is not because of his lack of understanding of technology - he holds an advanced degree in computer science as do most of his employees. There are too many companies moving education online and the official education is also taking place online. Fierce competition, for one thing, makes it difficult to make enough profit to balance the efforts in developing content and maintaining online-based educational operation. For another, students are getting their official school education online, sitting at the desk in their home, watching the computer screen all day. This is more than enough online time for a day for many younger children. Parents are becoming worried about the health and the eyesight of their house-bound children staring at the computer all day and they are less and less likely to sign up for extracurricular activities online. Hence, increasing competition 
over decreasing the market is what is happening to the extracurricular online education, and he does not think it wise to put the company's resources into developing online courses forced by the circumstances. He prefers a model that combines online and offline courses and offer different design based on customer needs. He thinks the online model is probably more suitable for university or high school students while younger ones will need more offline time. For the time being, Mr. Qian is outsourcing his team's skills to develop apps, software, and online content for other companies instead and is also exploring the possibilities of opening a not-for-profit subsidiary to provide innovation and design education to underprivileged students and get grants from foundations.

Previous three companies are in the typical service sector and suffered from the loss of the customers but the following three examples are technology-based startups that produce disinfectant (Company D) and Robots (Company E and F). Of these three, Company D and E are both currently being incubated at neoBay Venture Capital and they are examples that found new opportunities during the crisis, and Company $\mathrm{F}$ however is a representative case of a startup suffering from the investment freeze during the pandemic.

Company D was established in February 2017 and its main business is producing disinfectant. It currently employs close to a hundred workers and for apparent reasons, this is a company that faced the opposite problem from the three previous examples in that they met a huge increase in demand due to the pandemic.

Since the pandemic became a global phenomenon, the company has been receiving orders from all over the world (except for the USA) and received 20 million RMB amount of orders just in March and April 2020. The challenge for the company was to meet this sudden increase in demand. Travel restriction proved to be the major huddle. On the one hand, the supply chain had been broken as suppliers of some crucial materials became difficult to reach and factories were not operational in response to the government's policy of lockdown. On the other hand, travel restrictions disrupted the movement of goods and business meetings. The company had to quickly build up the capacity to meet the sudden increase in demand under such circumstances that meant hiring more workers who faced overtime works, identifying and preparing more factories, and at the same time managing international customer relations. According to Dr. Yan, the founder of the company, government support was crucial in making all these happen, and being in neoBay made it easier to communicate with the government. The first significant increase of the order since the outbreak of the pandemic was the government in line with the policy to promote entrepreneurship and at the same time fight the spread of the virus. Then, the government directly provided funds to help the company build factories to speed up the production process and gave travel permits to the company's staff so that they could move across the country bypassing the lockdown and negotiate with more factories and suppliers. The government and neoBay also helped the company to get loans from various SME stimulation funds from banks while also providing tax breaks and lowering rents which all other SMEs received for the hardest period of the pandemic.

The experience of the company has left them with a large customer base all over the world and now it is exploring to utilize this newly acquired asset to new business 
opportunities in other areas where the company can exert impact through a new line of medical products as well as disinfectants for households and communities.

Company $\mathbf{E}$ is another technology startup that was established in neoBay in November 2017 and started operation in April 2018. The main business of the company is producing robots for smart manufacturing, integrating AI with manufacturing robots. Until the time of the pandemic, the company's main clients were manufacturing factories. Since factory production halted and market shrunk due to the lockdown, 2020 would have been a very bad year for the company. On top of that, buyers of the company's robots would require actual demonstration that no online meetings can satisfy and the nation-wide lockdown would have affected the company negatively in this respect as well. According to the marketing manager Ms. Liu, during the pandemic, the company did try some online meetings using video demonstration of the products with the customers, but it proved to be less effective than real offline demonstrations.

Nevertheless, the company responded to these challenges of the pandemic in an active and timely manner by putting efforts into redesigning their robots to help fight the pandemic. To be specific, the company came up with five kinds of medical apparatus and instruments that can be deployed at hospitals: mobile food delivery robots, drug delivery robots, waste disposal robots, patrol robots to measure temperature and intelligent disinfectant. According to Ms. Liu, the invention of these robots coincided with market demands and social requirements. And the sales of these products and the cooperation with more partners helped the company not only to survive but prosper during the pandemic. Ms. Liu has an interesting story behind the invention of a patrol temperature measuring robot. On the eve of Chinese New Year, Dr. Zhang, the CEO of the company, received a phone call from one of his friends who worked at a hospital, complaining about the inconvenience of the temperature measurement system in hospitals. After receiving this call, Dr. Zhang immediately called his team to research and develop a new product to help solve this issue utilizing their specialty in AI-empowered robots. The whole of the technical team worked without rest for three days, over the Chinese New Year, and finally got the prototype built. When the pandemic swept across the country in force after the Chinese New Year, the company was ready with the very product that the country and the world needed.

Similar to the case of the company D mentioned above, company E also received similar support from the government and the new product helped the company open up a new market with customers from all over the world. The success was also, in large part, due to the dedication of the team that worked efficiently and tirelessly to develop and introduce new products as well as making upgrades and customization to meet further customer needs. According to Ms. Liu, this has been a very different experience from the standardized procedures and routine cooperation that the company had for years before the pandemic with manufacturing factories. They were also working with different and more diverse customers such as hospitals, schools, and even some tourist attractions. This led the company to develop more varieties of robots compared to the time when they were only working with factories, providing more challenging tasks for the team. All these led to the company becoming something very different from what it used to be before the pandemic, 
they became an even more closely knit team than before and this transformation will remain after the pandemic. What made this possible? In answering this question, Ms. Liu, echoing the CEO of the company Dr. Zhang, emphasizes the word 'responsibility' as against 'opportunity'. What motivates the individuals to work in teams to put more effort even during the biggest holiday and continue to work together towards moving target is the sense that they are doing the right thing for the society, rather than doing a clever thing to increase the company's profit. It is this sense of responsibility that gives the team a sense of joy in making a positive contribution to the world through what they do.

Company $\mathbf{F}$ is also a technology-based startup company in robotics that specializes in designing cleaning robots. Established in 2017, it was growing smoothly before the pandemic and started another round of investment in November 2019. Then the pandemic happened to interrupt the whole process of seeking investment. The same policy that helped Company D and E worked against this company. As we examined in the case of company $\mathrm{D}$, many factories were reoriented to produce equipment and material necessary to fight the pandemic. One of the key components for the cleaning robots is the brushes, and during the pandemic, those factories that make brushes for cleaning robots were 'recruited' to make masks and other medical supplies: workers in these factories were either occupied or forced to stay at home. The shipment of other raw materials and components was also disrupted. The orders placed before the pandemic was delayed for about two months and did not recover until the second half of April. Besides, as company E experienced concerning their key product before the pandemic, company $\mathrm{F}$ also faced difficulties in getting new contracts with customers due to the lack of the means to demonstrate the product and services. On top of that, many of his target customers, which include hotels and restaurant chains, were undergoing difficult times of their own due to the travel restrictions.

Financial troubles were inevitable for this company. Investment deals that had started in November 2019 have not finalized and made no progress since the Chinese New Year. Mr. Yao, the founder of the company, tried many other potential investors but has not been successful so far. This is pushing him to go into 'hibernation' mode. At least, he found some help from the government policy. Shanghai municipal government gave it a full three-month delay of payment, of social security accumulation funds, saving up to 20 thousand yuan per month per employee. Mr. Yao is not worried about survival. He hopes that the venture capital will eventually resume normal operation in May as well as his suppliers and customers. Venture capital or other forms of investment are coming back, staying alive and active in the first week of May. He predicts exponential growth for intelligent robots in the future and emphasizes the significance of offline life as human life is still mostly anchored in the real world, not in the virtual online world. To be more specific, even after the pandemic, the restaurants and hotels would still be recovering from their loss during the pandemic and continue to suffer from low demand, high rents, and high labor costs, it would be natural for them to switch to robot employees rather than a real human who desire 
monthly wage. According to Mr. Yao, the pandemic did not destroy his business but "it's a delay in responses, and you need to have guts and stick to your intuition and instinct."

\subsection{Discussion}

The key findings from the cases can be summarized in Table 8.2.

There are not many surprises in terms of the opportunities and challenges created by the COVID-19 pandemic for the startups in China. The pandemic created some opportunities through increased demand in existing products (disinfectants) or new market (thermometer robots) as well as government incentives in activities related to fighting the spread of infection but it proved to be a challenging time through diverting customers into online and freezing investments. The policy of lockdown as well as the diversion of resources to fight pandemic created supply chain paralysis for some businesses too.

Companies that could not find alternative business models went into 'hibernation' or inactive survival (Company F) while others continued to remain active for survival, trying different methods following the migration of the customers into online space, though without a clear business model (Company A, B). One company engaged in bricolage, utilizing existing skills and outsource itself to others, as in Company $\mathrm{C}$ that builds apps and software for other companies. Survival was still possible because of the small size and some government support such as tax break, rent cancellation and delays in social security payments. Although none of the companies interviewed received direct financial support from the government or banks for survival, after downsizing and furloughing survival was not a big problem for them.

Companies that were able to make use of the opportunities expanded their businesses during the pandemic. These were companies that had been either producing items that faced increased demand such as disinfectants as in company D, or that could very quickly develop new products that filled the market needs. The existence of a motivated and skilled team as well as government incentives also played an important role in such expansion. The relationship between different impacts of the COVID-19 pandemic and the responses are summarized in Fig. 8.3.

There are not many surprises in both the impacts of the pandemic on startups. There are, however, some important lessons we can draw concerning the responses to the challenges and the future of the post-pandemic world. 
Table 8.2 Key findings from the cases

\begin{tabular}{|c|c|c|c|}
\hline Company & Challenges & Responses & $\begin{array}{l}\text { Prospects for post } \\
\text { pandemic period }\end{array}$ \\
\hline $\begin{array}{l}\text { Company A } \\
\text { (cultural } \\
\text { immersion } \\
\text { tourism) }\end{array}$ & $\begin{array}{l}\text { Loss of customers due } \\
\text { to the ban on } \\
\text { international travel }\end{array}$ & $\begin{array}{l}\text { Job cuts, salary cuts, } \\
\text { increase } \\
\text { communications, create } \\
\text { virtual tours and online } \\
\text { events }\end{array}$ & $\begin{array}{l}\text { The online components } \\
\text { are inevitable currently, } \\
\text { but it is hard to say if } \\
\text { these will become a } \\
\text { part of the central } \\
\text { business model in the } \\
\text { post-pandemic period. } \\
\text { The evaluation will } \\
\text { have to be made later }\end{array}$ \\
\hline $\begin{array}{l}\text { Company B } \\
\text { (educational } \\
\text { exposure) }\end{array}$ & $\begin{array}{l}\text { Loss of customers due } \\
\text { to lockdown (domestic } \\
\text { travel and nonessential } \\
\text { crowd gathering ban); } \\
\text { lack of online-based } \\
\text { business model }\end{array}$ & $\begin{array}{l}\text { Exploring online-based } \\
\text { events using existing } \\
\text { social media platforms } \\
\text { to maintain contacts } \\
\text { with customers }\end{array}$ & $\begin{array}{l}\text { Returning to } \\
\text { offline-based } \\
\text { experiential tours but } \\
\text { supplementing it with } \\
\text { online events to } \\
\text { acquire, maintain, and } \\
\text { grow customers } \\
\text { Boundaries between } \\
\text { different types of } \\
\text { businesses are } \\
\text { becoming fuzzier and } \\
\text { the contents will } \\
\text { become more } \\
\text { important than brands } \\
\text { in the future of } \\
\text { education business }\end{array}$ \\
\hline $\begin{array}{l}\text { Company C } \\
\text { (Innovation and } \\
\text { design education) }\end{array}$ & $\begin{array}{l}\text { Loss of offline } \\
\text { customers; stiff } \\
\text { competition for online } \\
\text { education; parents and } \\
\text { students becoming tired } \\
\text { of too much time spent } \\
\text { online }\end{array}$ & $\begin{array}{l}\text { A mixed approach } \\
\text { combining online } \\
\text { element and offline } \\
\text { interaction } \\
\text { Providing app } \\
\text { development services } \\
\text { for other companies } \\
\text { Exploring not-for-profit } \\
\text { subsidiary funded } \\
\text { through grants }\end{array}$ & $\begin{array}{l}\text { Companies are going } \\
\text { online not because of } \\
\text { this is an opportunity } \\
\text { but because this is the } \\
\text { only option at the } \\
\text { moment } \\
\text { He expects online } \\
\text { education to } \\
\text { supplement the offline } \\
\text { model not replace it }\end{array}$ \\
\hline $\begin{array}{l}\text { Company D } \\
\text { (Disinfectant) }\end{array}$ & $\begin{array}{l}\text { A sudden increase in } \\
\text { demand; broken supply } \\
\text { chain }\end{array}$ & $\begin{array}{l}\text { Expanding team; } \\
\text { Received government } \\
\text { Support }\end{array}$ & $\begin{array}{l}\text { Expand the application } \\
\text { of the existing product } \\
\text { and target market. } \\
\text { Build international } \\
\text { cooperation }\end{array}$ \\
\hline $\begin{array}{l}\text { Company E (Smart } \\
\text { Manufacturing } \\
\text { Robots) }\end{array}$ & $\begin{array}{l}\text { Decreased demand in } \\
\text { the existing market; } \\
\text { logistics disruption }\end{array}$ & $\begin{array}{l}\text { New product focusing } \\
\text { on social needs; } \\
\text { received government } \\
\text { support }\end{array}$ & $\begin{array}{l}\text { New business } \\
\text { approach, new } \\
\text { customers, new market }\end{array}$ \\
\hline
\end{tabular}


Table 8.2 (continued)

\begin{tabular}{l|l|l|l}
\hline Company & Challenges & Responses & $\begin{array}{l}\text { Prospects for post } \\
\text { pandemic period }\end{array}$ \\
\hline $\begin{array}{l}\text { Company F } \\
\text { (Cleaning Robots) }\end{array}$ & $\begin{array}{l}\text { Production halt; } \\
\text { supply chain } \\
\text { disruption; } \\
\text { lack of investment }\end{array}$ & Hibernation & $\begin{array}{l}\text { Demand for robots to } \\
\text { replace manual labor } \\
\text { will increase }\end{array}$ \\
\hline
\end{tabular}

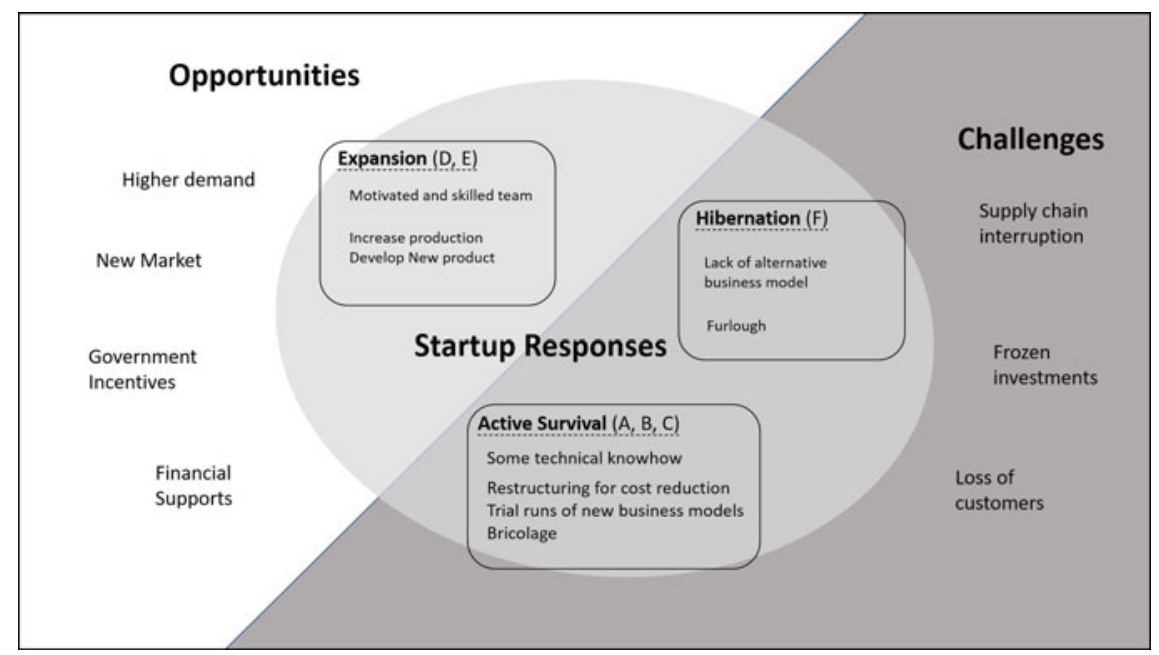

Fig. 8.3 Startup responses to COVID-19 opportunities and challenges

\subsubsection{Use of Online Technologies}

There was no doubt a shift to online education. The shift was very sudden, with many users and providers of education not having online experience. COVID-19 even expanded the online education to a new user base of kindergarten and primary students (Kologrivaya and Shleifer 2020) shifting over 278 Million students online. The managers of two companies in education that we have interviewed all had some background in computer engineering and are not expected to face particular technical difficulties in moving online. Company $\mathrm{C}$ had experienced providing online education services before the pandemic. The current study reveals, however, that there are reasons for caution towards online-based services as a replacement for the face-to-face interaction even during the lockdown. Although it might be true that students, parents, and teachers have become more accustomed to online-based teaching/learning, this does not mean it will be appropriate for all ages. Parents of young children are becoming worried about the lack of outdoor activities by their children and the same concern should also be a concern for older students and teachers. Also, the current exodus to the online environment is more because there is no other 
option than because the businesses see the benefits or profits out of it. Many of them seemed to have dipped into online services without a clear business model or pricing plan and once this experiment is over, there will be a calculation of cost and benefits through which businesses will have to make their own decisions regarding the mix of online/offline components. How many of them will remain or even utilize online components remains to be seen. Even for companies with technical knowledge, developing new online business and content takes time and resources but the market is already saturated and cannot guarantee a profit. Besides, the effort spent to acquire the technical support for the shift to online may not pay off because the competition is too stiff, and since it may not be used in the post-pandemic period.

Online-based interaction also has limitations in replacing face-to-face meetings and visits from which important business deals are made. Both companies $\mathrm{E}$ and $\mathrm{F}$ that build robots for institutional buyers before the pandemic found that they could not effectively replace face-to-face demonstrations with online demonstrations, as the latter could not generate enough sense of trust in the potential customers. A similar problem can be raised regarding the lack of investment during the lockdown. One reason that investment in startups froze during the lockdown is that the investors need face-to-face meetings observing the applicants and their team in the place of their work to get full information that the applicants themselves do not reveal voluntarily. This is especially true for venture capital which invests in people. Since the investors have many uncertainties about the future and how they want to use their money, investors require multiple meetings with companies before they can decide to go ahead with investing in the company. Not able to meet these startups in person makes it difficult for investors to gauge the progress and trustworthiness of the investment. Whether this kind of business meeting can be replaced by an online concall is questionable. Even with the promise of blockchain technology that ensures a possible decentralized method of building trust among the two parties, (Liang et al. 2017) to make such principle apply to the subjective field of VC investment is not going to be easy. As the VC capital insider points out, "sometimes it is entirely based on people and the feeling they give out. You cannot get it from an online conversation, website, or documents transferred over email".

\subsubsection{The Role of Entrepreneurship Ecosystem for the Startup Survival}

Observing all the cases, it is important to note the role played by the government and other components of the entrepreneurship ecosystem involving VCs and incubators. Company $\mathrm{F}$ is an example that faced challenges due to government actions during the pandemic. The policy to divert available materials and resources to factories manufacturing for the needs of the pandemic was a necessary move but it broke the supply chain of startups that use the same resources. Yet, it also benefited from government policy to delay social security payment for employees that was crucial 
for its survival. From the start of the official recognition of the outbreak and implementation of lockdown policies, various governments in China, as in other countries, provided supports for the startup companies to survive. For example, the Shanghai Municipal government, as well as the Minhang District government, issued policy measures including:

- Increasing the financial assistance for enterprises to alleviate the difficulties

- Increase the subsidies for stabilizing positions of enterprises

- Supporting key epidemic prevention materials supply and marketing enterprises to expand production (Shanghai Municipal Government, February 7, 2020; see also Shanghai Bendi Daily, February, 12, 2020).

Not only for survival, but the government efforts to fight the pandemic can provide an opportunity for a company in the right business area. Both the company D and E were helped by the government in lining up factories for production and developing sales channels. For these companies, finding financial resources to fund the new opportunities for expansion was a key to success.

This is the point where an entrepreneurship ecosystem can play a vital role in the survival of startups. The entrepreneurship ecosystem provides a meeting place for the government, banks, and startups creating a sense of mutual trust between all the parties involved. This helps bridge the information asymmetry between financers and startups and provides each party with the necessary trust to start the conversation that leads to deals. Both companies D and E, that experienced a tremendous increase in production during the pandemic were able to do so because of the loans from banks arranged through the neoBay and it only took 2 weeks from initial contacts to the delivery. Apart from these two examples, neoBay has helped 25 companies receive special grants issued by the Science and Technology Commission of Minhang District; it also helped dozens of companies receive special lowinterest loans from Shanghai Minhang Bos Rural Bank during the pandemic taking advantage of the simplified procedure by-passing conventional credit application process. Apart from finance, neoBay works as an information-sharing platform for available resources and promotional policies by the government, it also provides connections with companies both inside and outside the ecosystem, from SMEs to Fortune 500 companies, to help companies access horizontal and vertical integration. It also provides other services such as mentorship and all of its services have been available online from the period before the pandemic. With the establishment of the IEIE in 2019, now such benefits have expanded to international markets and business partners through international co-incubation processes. All of the 470 startups in neoBay have survived the lockdown and such findings are consistent with what has been observed in Germany by Kuckertz et al. (2020) in that "startups rely heavily on the support of their entrepreneurial ecosystem to manage the crisis" (Kuckertz et al. 2020, 8). 


\subsection{Concluding Remarks}

As mentioned at the beginning of the chapter, there is a good amount of gloom over the future of startups with a sliver of hope for them lies in their ability to adopt a technology-based business model successfully. This chapter provides some insight based on the experience of the businesses in China that met the full force of the "Great Lockdown" before any other country. Although this case study cannot be a comprehensive representation of the whole story, some implications become obvious. First, the investment freeze is real, and this reveals the limits of online and ICT technologies in assisting VCs in making investment decisions. This is due to the limits of online-based communications in delivering contextual or ambient information and other non-deliberate information to the participants. The same reason limits the ability of the online-based medium in making important business deals. Second, despite this, startups can survive. Some necessary adjustments in the workforce and operational procedures can be painful, but due to the small size, startups can survive after downsizing for a couple of months. Third, some startups can utilize technology to create a new market but this needs much more than technology. Versatile and motivated team to make the shift in the product, services, and business models in time; access to information regarding government support; ability to fund the expansionall these non-technological elements become important factors. Fourth, the current trend in online utilization will leave a certain mark, but whether it will be a replacement or a disruption to existing industries in service, even in education, depends on the assessments of the online-based learning experiences during the current lockdown including the self-assessment by the business owners of their experiments. Finally, the current lockdown is providing an opportunity for all to experiment with things online and makes the society look for technological solutions but for this to become an opportunity much more than knowledge of technology is needed, and an entrepreneurship ecosystem can provide a platform to link all these resources, information, and network to help individual startups weather the storm.

Acknowledgements The authors would like to thank Mr. Yue Yu, Ms. Yang Chen, and Ms. Xinyi Zhou for assisting in the interview and also the CEOs and staff of the companies who have kindly consented to provide valuable time and information for the project.

\section{Authors' Insights}

Although $\mathrm{VC}$ investment has not fully recovered, the doomsday scenario of six months' freeze wiping out the majority of startups as cautioned by the World Economic Forum does not seem likely, at least in China. Yet, there are some visible signs that investors are becoming more cautious in venturing into startups, creating the tendency for the investment to concentrate on a few promising projects. As VC insiders told us during the interviews, "investors compete against each other to get 
their fingers on few good projects, while most of the projects cannot find investments". Therefore, the pandemic and the post-pandemic world will still be a testing ground for entrepreneurs.

To be able to remain standing in such a harsh environment, a versatile team, willing to try different methods, able to work with different partners to serve a different market, will be needed. Inclusive entrepreneurship ecosystems can provide entrepreneurs with means of exploring a new market, chances of acquiring required skills at a lower cost, and access to resources or support by providing extra trust to buyers or investors. Most of all, entrepreneurs need to be passionate about their mission that stays true through changing circumstances and compromises: the passion that enables them to motivate themselves, their teams and inspire others around them; a sense of purpose that guides them through the storms of disruptions and works as an anchor around which changes are purposefully made, not being aimlessly tossed by the winds and waves of the storm; a sense of achievement that comes from the conviction that their products and services are making positive contributions to the world.

The post-pandemic world will be different. The coronavirus-19 pandemic has brought significant loss and damage to the whole world and has changed the way we live, work, socialize, and think. Even when this pandemic is over, we will still see another pandemic or similar challenges in the future. We need to solve the present and future problems in a new way. Entrepreneurs need to use their wisdom and ability to contribute to a better tomorrow. Changes in society often provide abundant opportunities for innovators and entrepreneurs. Facing the challenge bravely, abandoning the shackles of the past but thinking from the perspective of the future, this might well be the best time for entrepreneurs.

\section{References}

China Daily. (2020, January 22). China orders schools to make emergency plans for new coronavirus pneumonia. https://www.chinadaily.com.cn/a/202001/22/WS5e2838c5a3101 28217272d66.html.

China Daily. (2020, February 1). Coronavirus battle in China: Process and prospect. https://www. chinadaily.com.cn/a/202002/01/WS5e358377a3101282172741d2_3.html.

China Daily. (2020, March 24). Lifting of lockdown on Hubei sends back-to normal signal. https:// global.chinadaily.com.cn/a/202003/24/WS5e79f672a310128217281ae0.html.

Chinaventure.com.cn. (2020, June 24). Large number of foreign LP betting on China's capital market, with VC/PE investment rebounding after a short fall in May. https://www.chinaventure. com.cn/report/1005-20200615-1619.html.

CNBC. (2020, March 31). Startups cut nearly 4,000 jobs in March as coronavirus impact ripples through tech. https://www.cnbc.com/2020/03/31/coronavirus-and-start-ups-almost-4000-job-los ses-in-march-alone.html.

CNBC. (2020, April 22). In a crisis, some start-ups are surging-And saying 'no thanks' to hungry investors. https://cnbc.com/2020/04/21/start-ups-surging-in-coronavirus-lockdown-dec line-venture-money.html.

Financial Times. (2020, March 18). Coronavirus proves a bonanza for Asia edtech start-ups. 
IMF. (2020). World economic outlook, April 2020: The great lockdown. https://www.imf.org/en/ Publications/WEO/Issues/2020/04/14/weo-april-2020.

Kologrivaya, E., \& Shleifer, E. (2020, March 26). Quarantined: China's online education in the pandemic. The Diplomat. https://thediplomat.com/2020/03/quarantined-chinas-online-educat ion-in-the-pandemic/.

Kuckertz, A., et al. (2020). Startups in times of crisis-A rapid response to the COVID-19 pandemic. Journal of Business Venturing Insights, 13, 1-13. https://doi.org/10.1016/j.jbwi.2020.e00169.

Liang, X., Shetty, S., Tosh, D., Kamhoua, C., Kwiat, K., \& Njilla, L.. (2017). ProvChain: A blockchain-based data provenance architecture in cloud environment with enhanced privacy and availability. In 17th IEEE/ACM International Symposium on Cluster, Cloud and Grid Computing (CCGRID), Madrid (pp. 468-477). https://doi.org/10.1109/ccgrid.2017.8.

Shanghai Bendi Daily. (2020, February 12). Minhang District issues 10 policies supporting the stable development of enterprises. http://sh.bendibao.com/news/2020212/216561.shtm.

Shanghai Municipal Government. (2020, February 7). Notice of the policies on the epidemic prevention and supports \& services to the sustainable development of enterprises by Shanghai Municipal People's Government. http://www.shanghai.gov.cn/nw2/nw2314/nw2319/nw10800/ nw42944/nw48506/u26aw63478.html.

South China Morning Post. (2020, February 21). Chinese start-ups scramble for cash as venture capital investments freeze amid coronavirus outbreak. https://scmp.com/business/banking-fin ance/article/3051756/cash-crunch-chinese-start-ups-scramble-cash-venture.

World Economic Forum. (2020). This is what COVID-19 did to start-ups in China. https://weforum. org/agenda/2020/05/covid-19-s-coronavirus-startups-china-funding/.

Xin Min Wan Bao (New People's Evening News). (2020, March 10). Shanghai GDP reached 3.8 trillion RMB in 2019. http://baijiahao.baidu.com/s?id=1660740487393152968\&wfr=spider\& for $=$ pc.

Xinhua News. (2020, May 11). Shanghai Disneyland reopens with controlled capacity. http://www. xinhuanet.com/english/2020-05/11/c_139047735.htm.

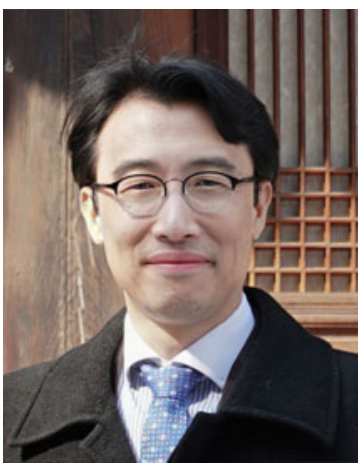

Soong-Chul Ro has been teaching courses relating to the comparative political economy at the University of - Shanghai Jiao Tong University Joint Institute since 2010. He also works as the Assistant Director for the Center For Entrepreneurship of the UM-SJTU Joint Institute (JI-CFE, http://umji. sjtu.edu.cn/entrepreneurship) and coordinates the center's resources to provide entrepreneurship education through minor in entrepreneurship program and events such as Entrepreneurship Competition, Meet the Entrepreneur lecture series and International Entrepreneurship Week. His current works focus on sustainable development, social entrepreneurship and he has been leading several domestic and international participatory action learning/research projects such as 'mHealth for Belt and Road region' project and 'Bangladesh Challenge'. He has also been a practitioner of social entrepreneurship. Before the current appointment, he worked as a program manager of the Stepping Stones China, a local NGO in Shanghai providing free English education to children of the migrant population, and co-founded the New Voice Children's Choir for the migrant community. 

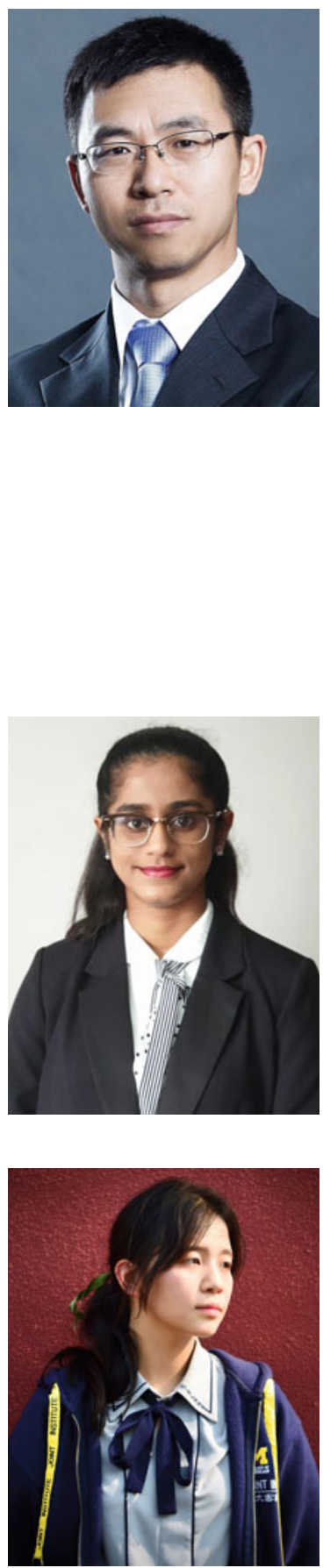

Zhigang Zhang has been working as the general manager of Shanghai neoBay Venture Capital co., Ltd. (neoBay: http://neo bay.cn) since 2015. NeoBay devotes itself to create community, space, and services for any type of startups, and is building a network with other innovation ecosystems from all over the world through a new initiative called International Ecosystem for Innovation and Entrepreneurship, to become the global head-stream of key technologies and industries. Prior to this appointment, he had long been engaged in innovation and entrepreneurship talent cultivation in China. In 2003, he established an "Information Technology Laboratory" in Shanghai Jiao Tong University as a non-profit, open laboratory with a social purpose. This was one of the earliest entrepreneurship spaces established in a university in China. He has also founded the Siyuan Community for Social Welfare and the InnoXYZ Innovation Service Platform. At the same time as being the general manager of neoBay, Dr. Zhang serves as an associate professor at Shanghai Jiao Tong University (SJTU), School of Electronic Information and Electrical Engineering and is in charge of the strategy department at the Advanced Industrial Technology Research Institute (AITRI, http://aitri.sjtu.edu.cn/) of the SJTU.

Niharika Dayaneni has a background in mechanical engineering and is an active member of the Center for Entrepreneurship (CFE) at the University of Michigan-Shanghai Jiao Tong University Joint Institute. Her current passion lies in finding solutions for social problems blending technology, design, and entrepreneurship. She has worked with animal welfare organizations in Singapore and is currently involved in an action research project in finding innovative solutions to combat the impacts of the COVID-19 pandemic.

Renan Chen is currently an active member of the Center for Entrepreneurship (CFE), at the University of MichiganShanghai Jiao Tong University Joint Institute, assisting various activities of the center using her leadership skills in a multicultural and multi-lingual environment of the center. She is particularly interested in using her background in computer engineering to develop an innovative and sustainable way of carrying out businesses. 
Open Access This chapter is licensed under the terms of the Creative Commons AttributionNonCommercial-NoDerivatives 4.0 International License (http://creativecommons.org/licenses/bync-nd/4.0/), which permits any noncommercial use, sharing, distribution and reproduction in any medium or format, as long as you give appropriate credit to the original author(s) and the source, provide a link to the Creative Commons licence and indicate if you modified the licensed material. You do not have permission under this licence to share adapted material derived from this chapter or parts of it.

The images or other third party material in this chapter are included in the chapter's Creative Commons licence, unless indicated otherwise in a credit line to the material. If material is not included in the chapter's Creative Commons licence and your intended use is not permitted by statutory regulation or exceeds the permitted use, you will need to obtain permission directly from the copyright holder.

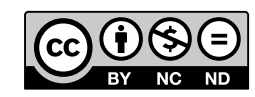

